in Carnegie Music Hall, with Dr. Weidlein presiding, addresses will be given by three Nobel prizemen, namely, Dr. Irving Langmuir (chemistry), Dr. H. C. Urey (physical chemistry), and Dr. W. P. Murphy (medicine). Brief addresses will also be given by Andrew W. Mellon and Richard K. Mellon, representing the founders. A symposium on "Recent Progress in Science" will be held on May 7. Speakers will include Dr. G. O. Curme, jun., Dr. F. B. Jewett, Sir Frederick Banting and Dr. W. W. G. Maclachlan. The new building, which has taken six years to complete, is to be dedicated to science and humanity in honour of Andrew W. and Richard B. Mellon, founders of the institution, who in 1911 gave support to the research fellowship system advanced by the late Robert Kennedy Duncan by establishing a specific department at the University of Pittsburgh, and in 1913 placed the system on a permanent basis with the organization of Mellon Institute.

\section{Discharged Soldier Settlers in New Zealand}

According to the report of the New Zealand Department of Lands and Survey on Discharged Soldiers Settlement for the year ended March 31, 1936, a further twelve applications for land were received during the year, seven of which were granted, making a total of 4,093 allotments, covering $1,440,818$ acres in the twenty-one years the Act has been in force. A grand total of $1,452,829$ acres has been proclaimed for this purpose since the inception of the scheme. Loans authorized during the year numbered 719, involving an amount of $£ 66,517$. Reports from the District Commissioners of Crown Lands indicated that the soldier settlers, most of whom are engaged in dairy farming or sheep farming, have had a better year, although those engaged in orchards again had a poor season owing to inclement weather.

\section{Rockefeller Foundation China Programme}

The Chinese Mass Education Movement, the Colleges of Public Affairs and Natural Sciences at Yenching University and the Institute of Economics of Nankai University received aid from the Rockefeller Foundation during 1935. In the part of the China programme centring round Nanking in south China, support was extended to the national health administration; to the Commission on Medical Education, and to three institutes interested in agricultural development; to the University of Nanking for its departments of agricultural economics and science; the National Central University for work in animal husbandry and veterinary preventive medicine; and the National Agricultural Research Bureau for insect control work. Local fellowships in China granted by the Foundation numbered 140 .

\section{Maintenance of Isothermal Chambers}

$A x$ the Institution of Electrical Engineers, Savoy Place, W.C.2, on May 5 at 6 p.m., Mr. L. B. Turner, a well-known radio-physicist of Cambridge, will present a paper describing a method he has devised of keeping a mains-operated isothermal chamber at a temperature constant to one thousandth of a degree centigrade. Although designed for a specific engineering application, it is likely to prove of interest to biological research workers and they are invited to attend the meeting. Biologists are specially interested in the maintenance of extremely constant tempera. tures ; for minute changes of heat production in living tissue, detected by thermocouple, have been used as an index of vital process; and these changes can be measured only when the body under examination is protected from temperature fluctuation imposed from outside.

\section{Conference on Large High Tension Systems}

THE International Conference on Large Electric High Tension Systems will be held in Paris on June 24-July 3. It was established in 1921 with the sole object of studying the problems connected with the high-tension transmission of power. The organization and interpretation facilities will enable anyone speaking English to profit fully by the work of the Congress. An attractive programme of visits and excursions has been arranged and special terms are offered by many of the hotels and railways to registered members of the Congress. Further details may be obtained from the Secretariat, Avenue Marceau, 54, Paris, or the Secretary, Institution of Electrical Engineers, Savoy Place, London, W.C.2.

\section{Travelling Fellowships in Medicine}

The Medical Research Council invites applications for six Rockefeller medical fellowships for the academic year 1937-38. They are intended for British graduates who have had some training in research work in clinical medicine or surgery, or in some other branch of medical science, and who are likely to profit by a period of work at a centre in the United States or elsewhere abroad, before taking up positions for higher teaching or research in the United Kingdom. The Council also invites applications for four Dorothy Temple Cross research fellowships in tuberculosis. The object of these fellowships is to give special opportunities for study or research to suitably qualified British subjects of either sex "intending to devote themselves to the advancement by teaching or research of curative or preventive treatment of tuberculosis in all or any of its forms". Further information and forms of application, returnable not later than June 1, are obtainable from the Secretary, Medical Research Council, 38 Old Queen Street, Westminster, S.W.1.

\section{Royal Aeronautical Society Awards}

ON April 26, Mr. H. E. Wimperis delivered his presidential address to the Royal Aeronautical Society on the subject of the natural limits to human flight, and the following medals and awards were presented : Society's Gold Medal to the late Señor J. de la Cierva, for his work on the development of the autogiro; Society's Silver Medal to F. W. Meredith, for his work on the automatic pilot; Society's Silver Medal to P. A. Cooke, for his work on the automatic pilot; British Gold Medal for Aeronautics to A. Gouge, for his achievement in the development of 
flying boats ; Simms Gold Medal to Dr. H. J. Gough, for his paper "New Light on the Strength of Materials afforded by Modern Physics" ; Simms Gold Medal to W. A. Wood, for his paper on "New Light on the Strength of Materials afforded by Modern Physics"; Taylor Gold Medal to Dr. G. P. Douglas, for his paper on "Cooling Problems with particular Reference to the work of the $24 \mathrm{ft}$. R.A.E. Tunnel" ; Edward Busk Memorial Prize to Mr. G. H. Dowty, for his paper on "Retractable Undercarriages"; Pilcher Memorial Prize to $\mathbf{H}$. Leaderman, for his paper on "The Fundamentals of Boundary Layer Theory with Some Applications to Aircraft".

\section{Current Sunspots}

AFTER some weeks of only moderate solar activity compared with the great activity shown from about last November until January, the recent appearance of an extensive active area of the sun may be noted. There are three chief groups of spots, one of them showing a rapid development from April 19, when the total area was only about 50 millionths of the sun's hemisphere, to April 22 when the area had increased to 1,750 millionths. Particulars of the groups of spots are as follows :

\begin{tabular}{cccc} 
Date on Disk & Central Meridian & \multicolumn{2}{c}{ Maximum } \\
Passage & Latitude & Area \\
April 15-28 & April $22 \cdot 4$ & $10^{\circ} \mathrm{S}$. & 650 \\
" $16-29$ & $" 23 \cdot 2$ & $25^{\circ} \mathrm{N}$. & 900 \\
" $18-30$ & $" 24 \cdot 6$ & $19^{\circ} \mathrm{N}$. & 1750
\end{tabular}

Bright hydrogen eruptions were observed in association with the largest group on April 21 between $11^{\mathrm{h}}$ and $12^{\mathrm{h}}$ and $15^{\mathrm{h}}-16^{\mathrm{h}}$ U.T., whilst a series of small but very bright eruptions occurred on April 23. Another bright eruption, more extensive than any of these, was observed at Greenwich on April 25 between $8 \frac{1 \mathrm{~h}}{2}$ and $11 \frac{1}{2} \mathrm{~h}$. Two magnetic storms were recorded at Greenwich beginning on April 24 at $12^{\mathrm{h}} 0^{\mathrm{m}}$ and on April 25 at $15^{\mathrm{h}} 45^{\mathrm{m}}$. For the first storm, the ranges in declination, horizontal force and vertical force were $46^{\prime}, 275 \gamma$ and $145 \gamma$ respectively, and for the second (up to April $2610^{\mathrm{h}}$ ) $30^{\prime}, 310 \gamma$ and $105 \gamma$ respectively. The second of these storms would seem to be related to the display of aurora reported by Mr. E. L. Hawke in The Times of April 27 as seen on April 25 from the Chiltern Hills.

\section{The Night Sky in May}

DURING the month, the duration of night decreases in the latitude of London by nearly $1 \frac{1}{2}$ hours. The moon is new on May 10 at $13 \cdot 3^{\mathrm{h}}$ and full on May 25 at $7 \cdot 6^{\mathrm{h}}$, when a penumbral eclipse takes place. The greatest altitude of the moon at meridian passage $\left(61 \cdot 2^{\circ}\right)$ is on May 12, and the least altitude, $15 \cdot 9^{\circ}$, on May 26. Venus is a morning star rising just ovor an hour before the sun; on and about May 24 the planet is at its greatest brilliancy (magnitude $-4 \cdot 2$ ). Conjunction with the moon occurs on May 8 at $15^{\mathrm{h}}$. On May 11 at $11^{\mathrm{h}}$, Mercury is in inferior conjunction with the sun, and a partial transit (invisible from Great Britain) of the sun's disk occurs the same day between $8 \frac{1}{2} \mathrm{~h}$ and $9 \frac{1}{2} \mathrm{~h}$. The planet Mars is conspicuous low down in the night sky and souths about midnight in the middle of the month. On May 19, Mars is in opposition, and nearest to the earth on May 28, when the apparent diameter of the planet is $18 \mathbf{1}^{\prime \prime}$. On May 24 at $18^{\mathrm{h}}$, there is a conjunction with the moon, Mars being $0.6^{\circ}$ northwards. Jupiter is a morning star of about mag. $-2 \cdot 0$ in Sagittarius. Saturn rises in the dawn and can only be located with difficulty. About May 5, the maximum of the $\eta$ Aquarid meteors occurs, the radiant being at R.A. $22^{\mathrm{h}} 32^{\mathrm{m}}$ : Dec. $-2^{\circ}$, and on May 24 that of the Herculids, the radiant of which is at R.A. $16^{\mathrm{h}} 36^{\mathrm{m}}$ and Dec. $+30^{\circ}$. Approximate positions for Comet Whipple (1937b) are given by Möller's ephemeris in I.A.U. Circular No. 653, as follows :

\begin{tabular}{crrrr} 
Date & R.A. & \multicolumn{2}{c}{ Dec } \\
May & 3 & $14^{\mathrm{h}} 21 \cdot 9 \mathrm{~m}$ & $+60^{\circ}$ & $28^{\prime}$ \\
" & 7 & $22 \cdot 7$ & 60 & 18 \\
" 11 & $23 \cdot 7$ & 59 & 58 \\
" 15 & $25 \cdot 0$ & 59 & 29 \\
" 19 & $26 \cdot 5$ & 58 & 49
\end{tabular}

All times in this note are in U.T. ; add $\mathrm{I}^{\mathrm{h}}$ to convert to Summer Time.

\section{Announcements}

The proceeds of the Daniel Pidgeon Fund for 1937 of the Geological Society of London have been awarded in equal proportions to Dr. G. F. Claringbull, who proposes to investigate the geology and petrology of the Ross of Mull granite, and Mr. F. W. Cope, who proposes to map the central region of the Derbyshire dome, and to correlate the Lower Carboniferous rocks of the area with those of North Wales, Westmorland, and the type section of the Avonian.

Prof. George R. Murray, emeritus professor of medicine in the University of Manchester, has been made a member of a Departmental Committee appointed by the Home Secretary to consider the question of compensation for card-room and other workers in the cotton industry disabled by respiratory diseases.

Dr. John B. Grant, of the Rockefeller Foundation, was recently decorated by the National Government of China on the occasion of the New Year with the Fifth Order of Beautiful Jade for his meritorious services in China. This order was awarded especially for his pioneering and developing public health work and in promoting medical education in China.

A Royal Rumanian Society of Genetics and Eugenics has recently been founded at Bukarest under the presidency of Prof. G. Marinesco.

WE have received from the Association of British Chemical Manufacturers, 166 Piccadilly, London, W.I, a copy of the second edition of the "Index to Acts of Parliament and Statutory Rules and Orders affecting the Chemical Industry", which comprises supplements bringing the work up to date to December 31,1936 . Copies may be obtained from the Association at the price of $2 s$. 6d. post paid, remittance accompanying the order. 